\title{
A Double Standard: The Respective Responsibilities of English and French-language Canada in the German Refugee Crisis
}

Pierre Anctil

Translated from French by Jonathan Kaplansky 

Deux poids, deux mesures: les responsabilités respectives du Canada de langue anglaise et de langue française dans la crise des réfugiés allemands > by Pierre Anctil, was published in "None is Too Many and Beyond: New Research on Canada and the Jews During the I930s and 1940s / Au-delà de None Is Too Many: Nouvelles recherches sur le Canada et les Juifs dans les années 1930 et I940," Canadian Jewish Studies / Études juives canadiennes. vol. 24, 2016: 16-37.

In their seminal work dealing with the refugee crisis of the late thirties and early forties, Abella and Troper describe the inner workings of the Canadian Federal bureaucracy with regard to admitting Jews from Nazi-occupied Europe. Their study, supported by solid archival work, demonstrates the complex and, at the time, hostile reception that Canadian politicians gave to Jews knocking on their door. The authors' narrative is much weaker, however, when they address the question of French Canada. In this article, I seek to demonstrate that Abella and Troper's conclusions regarding Francophones are not based on any conclusive documentation. Using recent historical research and French-language sources, a remarkably different portrait emerges of the way Quebec understood the question of Jewish refugees and reacted to their plight.

Dans leur travail pionnier sur la crise des réfugiés de la fin des années 1930 et du début des années 1940, Abella et Troper ont mis en lumière les rouages de la bureaucratie fédérale canadienne et sa position quant à l'admission des Juifs d'Europe. Leur analyse, basée sur un solide travail d'archives, démontre la perception complexe, et à cette époque, clairement hostile qu'avaient les politiciens canadiens des populations juives frappant à leur porte. Cependant, la qualité de leur analyse est bien plus faible quand ils abordent la question $d u$ Canada français. Dans cet article, je souhaite donc démontrer que les conclusions d'Abella et Troper concernant les Francophones ne reposent sur aucune documentation concluante. En mobilisant l'historiographie récente et des sources de langue française, il est en effet possible de donner une image bien différente de la façon dont le Québec a perçu la question des réfugiés juifs et a réagi à leur sort.

No historical study achieves perfect mastery over a complex period or issue - especially one that has not been returned to in over thirty years. One of the goals of this article is to reflect on how to best advance research on Canadian Jewish history based on new data and parameters that have hardly received any attention to date, without overwhelming readers with works already published. That said, one of the glaring weaknesses in None is Too Many, as in the history of 
many English-language works in the field, is the treatment of French-language Canada in its relationship with the Canadian Jewish community. The topic gives rise to specific methodological and conceptual difficulties that we will address while systematically examining the book by Irving Abella and Harold Troper republished in 2012.

Jewish Canadians, who arrived in the great wave of immigrants at the beginning of the twentieth century, soon realized that the country where they had settled was, by linguistic and religious affiliation, divided between two large groups, one of which dominated the other. For reasons that I will not address in detail here, the British English-speaking world soon became the Canadian Jewish community's fundamental point of reference, even in Montreal where the majority of the population was French-Canadian. ${ }^{2}$ The presence of a significant national Catholic French-language minority, concentrated mainly in Quebec, nevertheless played a decisive role in the way Canadian Judaism evolved. The political and cultural influence of the Catholic French-language minority gathered momentum over the last fifty years, and in several respects altered the search for identity of Jewish communities settled in Montreal. While Canadian Jews in the twentieth century looked toward English-speaking Canada for the ideological and political developments that greatly concerned them, they nevertheless were forced to take into consideration the aspirations of the French-Canadian elite. ${ }^{3}$

At Parliament in Ottawa, in the major federal institutions, and in various newspapers and publications, Francophones, to some extent, challenged established authorities and demanded rights for themselves as a national group. Since the time of Wilfrid Laurier, French Canada had, with some success, promoted a bilingual Canadian state and made social and cultural claims aiming to perpetuate its own culture. There is no doubt that such claims had an impact on Canadian society as a whole and influenced the judgment of the political class at the highest level. As Abella and Troper accurately point out in their 1982 work, when the German refugee crisis occurred, Canadian Jewish community leaders could not ignore these realities or Francophone public opinion. The study of relations between the two minority groups, Jews and French Canadians, takes on strategic explanatory value and raises fundamental historical questions that cannot be ignored in the field of Canadian Jewish studies. Analyzing and interpreting Canadian reactions to the Nazi persecution of Jews requires knowledge of the ideological and cultural positioning of French Canada before the Quiet Revolution. It was this issue that disturbed French language readers upon the release of None is Too Many. Very quickly it became apparent that the way the authors dealt with Francophone political actors in history and the accountability they 
assigned to French Canada in the crisis did not meet even the most basic expectations. That was the main objection raised in my review of None is Too Many that appeared in 1984 in Recherches sociographiques. ${ }^{4}$ How could the Francophone elite of the razos be singled out as being one of the main obstacles to admitting German Jewish refugees in Canada? A debate, one of the most virulent in Canadian Jewish historiography, revolved around Quebec society's alleged anti-Semitism: its repercussions are still felt today in certain circles. ${ }^{5}$

It is true, however, that when None is Too Many was first released, little credible research existed on relations between Jews and French Canadians in the first half of the twentieth century. Opinions were voiced on the topic in various books written in English for lay people, most of them without any real historical basis and reflecting deep-seated prejudice, often portraying Canadian Francophones as narrow-minded. ${ }^{6}$ Even more significantly, at that time very few French-language intellectuals and historians had ventured into the complexities of Canadian Jewish history, and no serious study emerged to support or invalidate Abella and Troper's approach. No one really knew exactly what French Canada had made of the negotiations undertaken by Jewish leaders in the I93os on behalf of the victims of the persecution in Europe, and the Francophone historians most likely to solve the mystery were busy with other issues, such as Quebec nationalism, which seemed more urgent at the time. While Abella and Troper's conclusions regarding the responsibility of the French-language elite seem indefensible at first, very little reliable data existed to clearly refute the co-authors' reasoning. In the mid-1980s, it was difficult to say where the flaw was exactly and to find a suitable way of addressing the issue. Abella and Troper used an intuitive process to analyze French Canada and relied on perceptions vaguely shared by many English-language observers. In the face of Francophone discrimination and anti-Semitism, the authors of None is Too Many tended to repeat what was common knowledge at the time their book appeared: that this discrimination was harmful for the Jews and a serious threat to all of Canada. An apparently insurmountable cultural and linguistic gap seemed to prevent Anglophone researchers from moving beyond this pigeon holing.

Remarkable progress has been made in the last ten years or so in terms of our knowledge of the topic. A new generation of Francophone academics have systematically collected new data on the historical relationship between Jewish people and Francophones in the twentieth century. Many of them have learned Yiddish and Hebrew in order to do so, and published comprehensive studies written with deeper understanding of the history of Catholicism and French communities in the country. Collaborations have also arisen in Montreal be- 
tween specialists in Quebec studies and researchers working in Jewish studies, making it possible to establish a long-term exchange of ideas, developing mutual reciprocity in terms of pursuing common intellectual issues. ${ }^{7}$ Such exchanges are absolutely essential if we are to move beyond the atmosphere that prevailed in Canadian intellectual circles when None is Too Many appeared in 1982. Such efforts have allowed researchers to nuance their hypothesis and adopt novel approaches, while drawing on a pool of new data available in several languages. Today we understand that the authors of None is Too Many, who were part of a different context, made several errors in perspective and historical interpretation, the traces of which can be found in their work. Some inaccuracies are due to a lack of credible data at the time. Others may be blamed on significant methodological errors - in particular, that of Abella and Troper's analysis of the French language press in Canada in the interwar period, which was key to their study. By misjudging the nature of French-language newspapers and their influence, the co-authors embarked on an erroneous path, which today is increasingly apparent. We will examine in greater depth this reasoning proposed in None is Too Many.

The most basic error Abella and Troper made in 1982 is believing French Canada to be unanimous in its perception of Judaism and its understanding of the German refugee crisis. This is a recurring theme throughout the book, which tends to treat the Francophone population as monolithic and of one voice in its antipathy toward the Jews. No attempts are made to qualify the insertion of the authors' opinions nor to differentiate among French Canadians: no class differences are examined, no competing political parties are mentioned, and no special circumstances are taken into account. Anti-Semitism appears to lump into one group all the various stakeholders of the time and all levels of Quebec society, with very few exceptions. The Canadian French-language press is thereby perceived as the instrument or mouthpiece of this monolithic fervour in opposing welcoming refugees. "Almost every French-language newspaper warned the government against opening Canada's door to European Jews," the authors assert, in the opening pages of their work. ${ }^{8}$ The same peremptory statement recurs to describe a very strong anti-immigrant, anti-Semitic speech made by Duplessis, then-Quebec premier, to Sainte-Claire in the fall of 1943: "The French-language Quebec press did not wholeheartedly support Duplessis or the more shrill nationalists; it did, however, demand the rejection of Jewish refugees. Except for the Montreal weekly Le Jour, [...] the French press spoke with one voice." This 1982 positioning is reasserted even more insistently in Abella and Troper's preface to the new edition in 2012: "Together, Quebec Church leaders, nationalist politicians, and the social elite united not only 
in support of a boycott of Jewish owned businesses but also in efforts to keep Jews out of the public square and, above all, to bar Canada's door to the further admission of Jews." ${ }^{\text {"o }}$ The authors do not repeat this error in their approach to English-speaking Canada, which is said to present significant contrasts in terms of political opinion wherein various factions confront each other in the public arena, even in terms of the immigration of refugees. In short, for both authors, French Canada at the beginning of the twentieth century does not appear to possess a normality equal to that of British-inspired Canada, where the forces of democracy and political partisanship divide the citizens into opposed factions.

Although some social and historical characteristics clearly distinguish Quebec from the rest of Canada, as attests the existence of openly expressed Francophone nationalism, the fact remains that the contrast between the two groups was relatively limited at this period in history. By 1933, the Quebec region had already become industrialized and was host to several large cities, including the country's metropolis, Montreal. It also had an educated class. Given this context, it is impossible to defend the myth of a Quebec removed from modernity, or entirely bereft of a culture of democratic institutions and internal political debate. Contrary to what Abella and Troper repeat, French Canada had strong differences of opinion on the Jewish question. In the I930s, significant Francophone personalities fiercely defended the rights of the Jewish population and fought anti-Semitism. This is especially true of Olivar Asselin, Edmond Turcotte, Henri Bourassa, and Jean-Charles Harvey, four important journalists who called upon their fellow countrymen to better respect religious minorities. .I For the most part, however, French Canadians at that time were not much interested in discussing the refugee question, disassociating themselves from their fate, whether the refugees were Jewish or not. Rather than accuse them of being hostile to Jews or of practicing wide-scale anti-Semitism, it would be more accurate to say they were indifferent to the suffering of other nations or simply absent from the debate. This was particularly the case with the Francophone popular press, which as a rule did not express any opinions on the Jewish presence in Montreal or on the situation of the victims of Nazism. If there was consensus on these topics, it was one of silence and ignorance. This is a far cry from the picture painted by Abella and Troper of a French Canada busily attacking Judaism and its followers. The Francophone daily newspapers, like those of English Canada, were also very often directly in the pay of various political parties that used them for short-term electoral gain. Liberals and Conservatives, Unionists and Nationalists in fact struggled for popularity through the press, which created a journalistic milieu that differed sharply from what the authors of None is Too Many describe. Seen in this light, Quebec society is anything but monolithic. 
Even the Francophones who supported anti-Semitism were divided into several schools of thought and fought among themselves. From this perspective, nothing justifies Abella and Troper's analysis.

While Quebec and English-speaking Canada resembled each other in certain respects, they clearly diverged on one basic issue: the real power that these populations wielded in the federation. Here Abella and Troper make another serious mistake: placing both societies on equal footing in terms of political power when they confronted one another in Parliament or in various federal authorities. Especially at that time in history, Francophones, as a minority, were painfully aware of their own social and economic inferiority. Quite separate from the Jewish question, several activists in French Canada, including the editorialists at Le Devoir, saw immigration as a threat to their existence and a means for British Canada to limit their demographic and political influence. In the early twentieth century, discussions focussing on receiving immigrants often gave rise to visceral fears regarding the anglicization and dispossession of Francophones. ${ }^{\text {I2 }}$ This continued until the Charter of the French Language was enacted in 1978. By contrast, British Canada appeared to perceive new immigrants in a positive light. For Anglophones, the phenomenon seemed to be an opportunity to recruit new citizens and settle areas in the country's peripheries. The distinction was due to the fact British Canada saw the immigrants as placing themselves under its wing and assimilating rapidly to the dominant culture. Francophones, on the other hand, experienced great concern in this respect only intensified by the memory of mass migration between the years 1904-1914. These impressions result not only from deep-seated prejudice and growing xenophobia in Quebecer communities, but also reflect the unequal relationship and domination to which Francophones were subject from Canadian federation since its creation.

Relations between Catholic Francophones and Canadian Jewish communities thus differed fundamentally from those that Canadians of British origin were able to create in a similar context. In the first case, both populations were minorities who suddenly found themselves in each other's presence through the hazards of history and geography; sometimes, in Montreal, they were also fierce economic competitors. The Anglophone elite, on the other hand, established a relationship of political authority and precedence with Jewish leaders, exclusive of any inclination to question or enter into open conflict. Nor did they have to convince their counterparts of the importance of reaching a reasonable middle ground. Given this situation, most often Canadians of British extraction found it pointless to use threats against Jews or express strong hostility. While Jews and British Canadians laid the foundations for a consensual relationship born of 
common understanding of the reasons of State, Jews and Francophones formed a conflictual relationship devoid of guidelines. This was partly because French Canadians were not in control of the federal bureaucracy and did not dominate the key sectors of the national economy, and partly because their political aspirations did not at first appear legitimate in a country with a British tradition. So when we look at how Anglophones and Francophones reacted to the Jewish presence in Canada, we have to avoid judging them identically. The same applies to the demands of Jewish community leaders regarding the German refugee crisis. In their reasoning, Abella and Troper give the impression that English and French Canada were equally distanced from the Jewish claims, which explains the authors' temptation to have both linguistic groups bear important responsibilities in acknowledging the failure they portray regarding the treatment of Jewish victims. This would be a valid point had the Francophones created a well-established political elite in the national capital and were responsible for administering extensive sections of the public service at the time of the refugee crisis. But this situation did not take shape in Ottawa until Prime Minister Pierre-Elliott Trudeau came into office in 1968 and the effects of Quebec's Quiet Revolution were felt. When some Francophones finally arrived at the helm of the government machinery in sufficient numbers to exercise a decisive influence, the refugee crisis had already subsided for at least a quarter of a century.

Reading None is Too Many, it becomes clear that French Canadians had no predominant influence in the sequence of tragic events that prompted the Canadian government to refuse entry to the victims of Nazism. Aside from a few entry-level civil servants, the federal public service was entirely dominated by unilingual Anglophones of British origin. Moreover, during the I930s, Canada was still administered as a colony recently freed from the political authority of London. No data presented by Abella and Troper indicates that Frederick Charles Blair and A. L. Jolliffe acted with any concern for French Canada or wanted to reflect the country's linguistic duality. At the other extreme, we do not see Francophones among those actively militating in favour of opening the country's doors to refugees of all origins. Not one member of Parliament was elected by a majority Francophone electorate within the federal political party most open to the grievances of the Jewish community. At that time, the Co-operative Commonwealth Federation (CCF)had practically no influence in Quebec. The CCF's leading MPs, Major James 'M.J.' Coldwell, Stanley Knowles and Clarie Gillis, could not properly express themselves in French. Even the Canadian National Committee on Refugees and Victims of Political Persecution (CNCR), founded in 1938 in Ottawa to present a united front in favour of a more liberal admission policy, did not include one influential Francophone personality. The CNCR reflected, deliberated, and acted 
only in English. None of its publications intended for the public was translated into French. In fact, the organisation was created by approximately twenty organisations and lobby groups from English Canada, including some with a religious vocation. To this core was added a small number of delegates from the Canadian Jewish Congress (CJC) and other Jewish lobby groups.

The dramatis personae were, however, better balanced in terms of MPs, who, following the 1935 and 1940 federal elections, were asked to form the two Canadian governments most concerned with the refugee crisis. This fairer representation stems from the fact that William Lyon Mackenzie-King's Liberals swept up almost all of the seats in Quebec in these two elections and included in their ranks a great many Francophone MPs. In 1935 and again in I940, Quebecers wanted to prevent Ottawa from implementing conscription for overseas service and rejected the Conservative Party outright. Eminent French-Canadian personalities including Ernest Lapointe, Fernand Rinfret, and Louis Saint-Laurent held prominent positions in King's Cabinet between 1935 and 1948. In this arena, where the Canadian government's main policies were established, we can imagine that Francophones played a decisive role in certain sectors. French-language MPs entering the government also were obliged to support the decisions made at the highest level and most of them had long shared the liberal ideology of Wilfrid Laurier and King.

Overall, French Canada's situation was still clearly inferior, but the prominence of French Canadians in the King Cabinet produced circumstances favourable for the country's political unity and for more positive perceptions. Here we should point out that Abella and Troper correctly mention that all Cabinet members shared responsibility for King's attitude to the European refugee situation. However, the authors do not succeed in irrefutably establishing that, more than their Anglophone counterparts, the Francophone ministers were driven by deep anti-Semitic feelings. In the positions that these individuals took in Parliament or released to the press there are no remarks motivated by hatred of Jews or filled with racial connotations. ${ }^{13}$ Like King, they had probably learned a long time ago to silence their deep feelings on the issue and not disclose their opinions in public.

It is difficult to believe, as Abella and Troper do, that King's ministers in Quebec had predominant influence on the federal government's approach to the European Jewish refugees. Nothing indicates that Lapointe made this a decisive issue in his political career nor that he attached excessive importance to it. The co-authors have no conclusive data on this issue and their claim that the Minister of Justice "corrected any cabinet back-sliding, including that by the prime minister," remains unproven in their work. ${ }^{\mathrm{I}}$ The same holds true for the 
idea that Anglophone federal politicians feared Quebec public opinion so much that they were paralyzed. To substantiate this position, the co-authors authors quote only one source: an article by the controversial journalist Harold Dingman that appeared in the journal Liberty in 1947: "Most politicians are fearful of Quebec, which wants no immigrants not of its faith."' This neglects the fact that the Francophone electorate and main spokespeople of the French Canadian nationalist movement did not win an issue deemed eminently more important: the rejection of conscription for overseas service. Despite fierce political opposition, despite King's official promises in the I940 election, and despite a strongly negative vote in the 1942 plebiscite, in the fall of 1944 Francophones had to resign themselves to the imposition of enlistment measures. This occurred at a time when one third of federal Liberal MPs were made up of Quebec MPs and King's cabinet included a record number of Francophones who all supported the government's decision. No issue was more important for Quebecers than this one. In fact, Abella and Troper are probably the only Canadian historians to believe that Quebec politicians of the I930s and 4os exerted such a disproportionate influence in relation to their number and could single-handedly influence Federal Government policies.

The third fundamental error of interpretation in None is Too Many is the claim that during this period Quebec society harboured forms of anti-Semitism markedly more vicious than the rest of Anglophone Canada. Such expressions of hostility, occurring at all levels of the French-language population, were supposedly a huge obstacle to the satisfactory resolution of the refugee crisis. Abella and Troper subscribe very strongly to this position, one they repeat often in their work:

The unyielding opposition of certain key officials, the depression, the general apathy in English Canada, the outright hostility of French Canada, the prime minister's concern for votes and the overlay of Anti-Semitism that dominated Ottawa combined to ensure that no more than a mere handful of Jewish refugees would find a home in Canada. ${ }^{16}$

In their depiction, the humanitarian sympathies of some Canadian politicians, including Prime Minister King, constantly came up against a huge obstacle: the visceral and irrational animosity of Francophones toward European Jewish immigration. On this the co-authors are adamant: "The realities King had in mind were the attitudes toward refugees in general and Jews in particular within Quebec. He was absolutely convinced that Quebec would react violently to the admission of Jewish refugees; and with reason." ${ }^{\prime 17}$ This perception was shared by a few Jewish MPs who worked to shift perceptions within the federal 
bureaucracy, and thus feared making their efforts public: "Any organized Jewish demand for refugee admissions might create a backlash among non-Jews, especially in Quebec."'18

While some voices were raised within Quebec society wanting Jewish immigrants fleeing Nazi Germany to be turned away, this in itself does not prove that all Francophones in the long-term developed more extreme hostility toward Jews in general. As we will demonstrate a little further on, the more the authors are adamant and peremptory in their claims regarding Quebec anti-Semitism, the more supporting evidence is lacking. In fact, here Abella and Troper repeat a point of view present in English-language historiography without criticizing it or examining it in any depth. It would have been more logical and appropriate to start with a different hypothesis, namely that in the twentieth century Anglophone Canada and Francophone Quebec produced different forms of anti-Semitism expressed through very different means. From an historical point of view, retracing the origin of differing negative perceptions of the two dominant groups appears more productive than seeking to compare them without any specific point of reference, and with no other end than to place blame after the event. Francophone anti-Semitism found its roots in the teaching of the Catholic Church's universal doctrine that indicated the Jewish people abased themselves by rejecting the figure of Christ. British Protestants, on the other hand, voiced their objections to the Jewish presence by appealing to racial notions. Bearing this in mind, we can more easily reconstruct the various discourses present in Canada in the I930s. French Canadians had a tendency to see Jewish immigration as an expression of insidious values contrary to the moral foundations of their society, whereas the Government of Canada, worthy reflection of the Canadian majority, raised barriers as to the potential candidates' ethnic and geographic origins, which inevitably led to very different remarks and objections in discursive spaces that did not necessarily overlap. ${ }^{\text {19 }}$ Are we to conclude that the forms of anti-Semitism in Quebec carried more serious consequences for the Canadian Jewish population?

The idea that Quebecers carry more guilt stems also from prejudices and opinions held by Jewish community leaders at the time, which the co-authors of None is Too Many should have presented as such. That is essentially the proof put forth by Abella and Troper. For example, the authors quote remarks made in 1939 by M. A. Solkin, an activist at the Jewish Immigrant Aid Society (JIAS): "The new government would no longer have to placate the whims of anti-Semitic Quebec or retrain the good graces of other reactionary elements in this country" [and so might adopt] "a more reasonable immigration policy." ${ }^{20}$ Later in the 
work we learn that "The JIAS director informed his officers that it was necessary to keep the decision quiet lest Quebec, learning of it, attempt to have it reversed, as it had succeeded in doing with previous schemes." when there was almost no contact between the leaders of Jewish organisations and the French Canadian elite. ${ }^{22}$ An impenetrable veil separated the two; most of the Jewish leaders did not read Quebec's French-language press: they did not know the language in which it was published. The intense emotion the Jewish community experienced in the face of Hitler's persecutions made any attempt at dialogue with Francophones opposed to easing immigration regulations rather problematic. Instead of pointing to the prejudices of the pro-immigration activists of the time, often refracted through anti-Catholic sentiments present in English Canada, the co-authors would have been better off recognizing the incomplete nature of these accounts. That, at the very least, would have been more in keeping with a measured historic approach, detached from the requirements of community activism.

The type of historical analysis chosen in None is Too Many also compels us to question the way the authors interpret the creation of the CNCR in December 1938. As we have seen, the organisation loftily set out to defend in Canada the cause of refugee victims of Nazism but chose to function only in English. Presided by Cairine Wilson and administered by Constance Hayward, both personalities of exceptional moral value, the CNCR launched an all-out campaign to convince the Canadian public to take a humanitarian stand in this, thereby hoping to create a shift in opinion powerful enough to force King to change his attitude before it was too late. Why was the CNCR inclined to ignore Quebec reality? The co-authors' statement that "No French-Canadian organisation was represented" ${ }^{23}$ implies that no Francophone lobby group deemed the issue important enough to join the ranks of the CNCR. This declaration is a little too convenient. The English Canadian pro-refugee organisation assisted all European refugees, the majority of whom, it claimed, were not Jewish. In these circumstances, it is hard to believe that the main reason no Quebecers were part of the CNCR was their strong anti-Semitic feeling. Admittedly, few French Canadians at the time stood up for increased immigration to the country; possibly the Francophones' lack of engagement was prompted by a feeling of relative indifference to the situation in Europe. Yet it is possible that the CNCR itself was at the origin of the misunderstanding, particularly in light of some of its members' condescending attitude toward the Canadian Catholic Church and French Canada. It also seems plausible to hypothesize that the main leaders of the CNCR did not choose to maintain sustained contact with the Francophone political elite and did not know how to approach its main representatives. In 
fact, it was only in the postwar period that the first French-language associations working on behalf of immigrants and refugees appeared, often within the auspices of the Catholic Church. ${ }^{24}$

Several members of the Protestant clergy had joined the CNCR and campaigned within the organisation as accredited representatives of a religious congregation. Before the Second Vatican Council, some circles of the Anglican Church and the United Church of Canada harboured a thinly veiled animosity toward Catholicism, perceived as being morally corrupt with a fondness for superstition. In addition to these unfavourable theological opinions, some individuals, very attached to British culture, had strong anti-Francophone prejudices. Negative remarks would surface spontaneously in speeches made by CNCR members and even in their writing, which the Francophone press could not fail to notice. It is not difficult to imagine that a defence of the refugees accompanied by a thinly veiled rebuke to Francophone Catholics was not likely to gain many followers to the cause in Quebec. Tensions escalated in the case of Reverend Clarence Edwin Silcox, a Minister of the United Church of Canada, that on two occasions his attacks were the subject of reproachful editorials in Le Devoir, including an article provocatively titled "Le problème de l'immigration et l'animosité anti-québécoise" [The issue of immigration and anti-Québécois animosity]." ${ }^{25} \mathrm{~A}$ controversial character and flamboyant orator, Silcox, on a few occasions, allowed himself to link French Canada's half-hearted attitude to the refugees with moral turpitude, attacking the Francophone episcopate for remaining silent and indifferent to the plight of the victims of Nazism. Silcox was a public figure with significant influence in English Canada. In 1934, he began a term as General Secretary of the Social Service Council of Canada, a religious organisation, and in 1940 was appointed Director of the Canadian Conference of Christians and Jews. ${ }^{26} \mathrm{~A}$ few years later, Silcox became leader of the World Alliance for International Friendship through the Churches. His ill-considered outpourings caused considerable damage to the cause of the CNCR in Quebec, offending the already keen sensibilities of Francophones at the time of the conscription crisis. Silcox's repeated insults also let us see how a sincere Catholic could have expected to have been received at the CNCR's executive office. Beyond the more specific question of Jewish persecution in Europe, it appears clear that in the late zos many Francophones and Anglophones were still incapable of entering into constructive dialogue with one another, even for a cause as urgent as that of the refugees. Ultimately, in addition to all the difficulties connected with the government bureaucracy, geography, and the brutality of Nazi methods, Jewish people who sought to enter the country also fell victim to the stubborn persistence of French and English-Canadians in maintaining insurmountable linguistic and religious barriers between themselves. 
After wrongly assuming that Francophone Quebec expressed itself in one sole voice on a host of issues, and believing that French and English Canada may be treated the same in terms of history, Abella and Troper then claim that anti-Semitism was more pronounced in Quebec society than in the rest of Canada. The authors commit numerous other blunders in their interpretation of the refugee crisis. Among other reasons, this is because they essentially judge $\mathrm{Ca}-$ nadian society using the I930s as their criterion and neglect to examine earlier periods more seriously. Such an approach unnecessarily conflates the incidence of anti-Semitic sentiment in the country with the entire twentieth century, and ignores that after 1929 the international political and economic context significantly drove up hostility toward immigrants, especially those of Jewish origin. In Quebec as in the rest of Canada, the negative social impact of the Great Depression convinced both the population and the government to advocate staunch isolationism. Hitler's arrival to power in January 1933 and the discriminatory anti-Jewish measures he implemented also had repercussions in Canada. An insidious racial propaganda campaign and very explicit anti-Semitic publications began to circulate in various communities throughout the country, both in English and in French. In the face of these difficult circumstances, and with the outpouring of words attacking Jewish people, many Canadians let themselves be persuaded to change their former point of view. Several became indifferent to the suffering inflicted upon religious minorities in Europe and ignored the serious events that newspapers reported on their pages in 1938-39, including the violent attacks in Germany against synagogues and Jewish communities. ${ }^{27}$ This new context provides the backdrop for the Jewish refugee crisis described in None is Too Many. Nothing like it can be found in the first thirty years of the twentieth century, either in English or French Canada. No period in the twentieth century was as favourable to the dissemination of anti-immigration and judeophobic prejudices as the one from 1929 to 1939.

That at least is the impression that arises from a close reading of editorials published in Le Devoir between I9Io the year the newspaper was founded and the end of the Second World War. During this thirty-seven-year period when two major personalities, Henri Bourassa and Georges Pelletier, were in charge of the daily, Le Devoir mentions Judaism or the Jews 209 times in its editorial pages. ${ }^{28}$ Out of an historical corpus of close to eleven thousand editorials, this roughly constitutes a proportion of $2 \%$. It is important to note here that only half these reflections appear negative or discriminatory in terms of the Jewish people of Canada or Europe In several cases, the newspaper only includes objective data about the Jews, not likely to arouse hostile reactions from readers in the Jewish community. Over the period studied, there are six editorials clearly hostile to 
Jews, especially with respect to Jewish immigration from Germany: $82 \%$ of these appeared under Pelletier's rein, specifically between 1932 and 1947. The greatest number of anti-Semitic barbs in Le Devoir appeared in 1934, 1936, 1938, and 1943, a rather compact mass of fifty-five editorials published mainly during the refugee crisis and the Second World War. That was when Le Devoir published all the comments promoting l'achat chez nous (buy local) and recommended the strict observance of Sunday in civil society. In 1934 the most acerbic exchanges occurred in the pages of Le Devoir between Omer Héroux and the leaders of the CJC. While eastern European Jewish immigration was at its peak in Montreal, from I9Io to 19I4, and then to a lesser extent between 1920 and 1922, Le Devoir did not express much interest in the Jewish community. Bourassa himself only put pen to paper five times in the newspaper to discuss Jewish presence in Canada, and twice to clearly denounce the anti-Jewish prejudices of his compatriots. ${ }^{29}$

We must therefore be wary of judging, as Abella and Troper do, French Canada's traditional position toward the Jews, using only the years of the Great Depression as our criterion. This brief period reflects neither the general climate of relations between the two groups in the twentieth century nor the attitude of the Francophones of Plateau Mont-Royal toward their Jewish neighbours. Quite the contrary, the data indicates that the untold suffering caused by the economic downturn in 1929, and fears regarding the possibility of a new global conflict, created a kind of withdrawal across all levels of Canadian society and intensified distrust of that which came from abroad. This reaction was also apparent in the Francophone population, so much so that it included Jewish people already well established in Montreal and especially those wanting to flee Nazi Germany to find refuge in Canada. The authors would have been wise to use more caution in addressing this topic in None is Too Many, as that could have led to better understanding of hostility toward Jews in the longue durée, particularly in Francophone Quebec. This same distortion appears in one of the main ideas the authors defend in their study, namely that French Canada's traditional anti-immigration position must be analyzed as a phenomenon very closely linked to anti-Semitism. On the contrary, Le Devoir's editorials clearly demonstrate that distrusting newcomers and great shifts of population toward Canada was above all due to Francophones seeing themselves as a minority. From its early days, Le Devoir hammered home that the Anglophone political elite saw mass immigration as a way to ensure that a British conception of the Canadian political arena would dominate. This led the newspaper managers to ask the federal government to put an end to any vague desire to rashly inflate the country's mass of population. In 1912, for example, Georges Pelletier wrote: 
Canada is rapidly becoming populated. Every year, thousands and thousands of immigrants land on our shores, settling in provinces in the West, and are granted citizenship, thereby accordingly decreasing the influence of Canadian-born people in the country's affairs. The latest statistics from the Department of the Interior on this topic will give pause to anyone somewhat worried about the country's future. For while immigration certainly contributes greatly to Canada's material development, when it is done any old way and without much concern for the future it can cause considerable damage to the provinces where it is directed as well as to the rest of Confederation..$^{30}$

Le Devoir's strong reluctance toward immigration does not necessarily indicate pervasive anti-Semitism, especially as the tiny fraction of Jews in this great shift is mentioned very little in the newspaper's pages prior to 1932. Before seeing federal immigration policies as a phenomenon in which Jews play a decisive role or that threatens to increase the Jewish population of Canada, owing to the Nazi regime's persecution in Germany, French Canadians strongly believed that federal immigration policies worked against them. Incidentally, Le Devoir maintained this position for a long time following the Second World War and after the end of the large influx of Holocaust survivors from Eastern Europe. Abella and Troper are also on the wrong track in their view of the Catholic clergy's attitude to the German situation of the I930s. They also bring up, without examining them, concepts current at that time in Anglo-Protestant communities that made up the backbone of the CNCR. Several priests from the United Church of Canada and several ministers from the Presbyterian Church of Canada deemed it important to put a great deal of effort into the refugee cause, because they were firmly committed to social justice and thought this was the way to treat the most destitute. That explains why a number of them publicly spoke out on this topic in 1938 , appearing on platforms generally reserved for political activists. In light of these very strong actions, the timid if not non-existent protests of the Catholic episcopate could appear to be tacit approval of the fate awaiting the Jews in Germany. The silence was all the more disturbing as Francophones played a decisive role in the Montreal church and several representatives closely associated with the social doctrine of Catholicism, including Le Devoir and L'Action catholique, showed reserve if not reluctance in the face of the arrival a large number of Jewish refugees. Reverend Silcox, for example, mentioned earlier, was quoted in Le Devoir in 1943:

Beyond the matter of political or constitutional right, as a clergyman and a Christian, I wish my country to assume a Christian attitude on the large issue of providing sanctuary for refugees from the most in- 
famous persecution in the last two hundred years. Canada has largely been prevented from doing what it ought to have done by the opposition of Quebec. [...] But to the best of my knowledge, the religious leaders of Quebec made no protest and acquiesced in the position. This shall be remembered whenever the three million murdered Jews of Europe are recalled, and to their everlasting disgrace..$^{3 \mathrm{~T}}$

Silcox, however, was forgetting that before the Second Vatican Council, the Catholic Church and its main leaders resisted becoming involved in the political arena or taking sides in debates considered to be first and foremost a matter for civil society. The overthrow of democracy in Germany, the establishment of a dictatorship in Italy, and the repression of religious minorities in Europe, even when practicing Catholics were the first victims, did not usually lead to an immediate reaction from the official Church under Pope Pius IX. It was not until the encyclical Mit Brennender Sorge [with burning concern], dated March 1937, that the Vatican doctrinally condemned certain aspects of Nazi political thought, and then only in veiled theological terms. The Church's silence was even more significant over the course of the Second World War, when major crimes were committed to an extent heretofore unknown in Western society. The withdrawal of the French Canadian Catholic clergy from the refugee crisis does not necessarily signify approval of the flagrant injustices committed or indifference to the suffering experienced by other communities. Rather, it should be seen as a difference of perception on how to understand the voicing of opinions and the political praxis. Those are historical concepts that should have appeared in None is Too Many to provide background perspective on the ideological confrontations of the 1930s. Largely dependent on the Catholic tradition, and because lofty issues were involved, French Canada did not become involved in the refugee crisis with the same political culture and same moral vision as Protestant Canada.

In addition to a number of crucial historiographical questions, too often supplanted by a more superficial approach, Abella and Troper's work raises serious methodological concerns. All Canadian handwritten or archival sources used in None is Too Many are in English, including ones involving government authorities, with perhaps the exception of Ernest Lapointe's personal archives. ${ }^{32}$ Among the hundreds of notes the authors include, only a few refer to French speakers, newspapers or organisations: probably fewer than ten. Nor do we find in Abella and Troper's study any in-depth work that directly or indirectly examines the position of Francophone Canadians at the time of the refugee crisis nor that uses supporting documentation in French. The authors rely on only three studies for their remarks about French Canada; the most recent of which dates 
from 1981: a doctoral thesis by Kenneth Kernaghan, Freedom of Religion in the Province of Quebec, submitted in 1966 to Duke University. Also included are LitaRose Betcherman's 1975 analysis, entitled The Swastika and the Maple Leaf, and the thirteen-volume study by David Rome published by the Canadian Jewish Congress between 1977 and I98ras Clouds in the Thirties; On Anti-Semitism in Canada, 1929-1939.33 None of these publications provide any in-depth clarity on the situation in French Canada in the I930s. In all likelihood, Abella and Troper either did not read or retained nothing significant of the abundant research that appeared in French on this topic in recent years. Nor are they interested in the many studies written from a Francophone point of view on the history of the Montreal Jewish community. Considering this methodologically flawed approach, it would have made more sense for the authors to admit they did not have the information in hand with which to look in depth at French Canada's contribution to the great Canadian debate on the Jewish refugees. In their defence, it is important to remember that almost all recent works that have appeared in English in the field of Canadian Jewish Studies suffer in one way or another from this lack of historiographical perspective.

The main difficulty with Abella and Troper's study is that it contains a glaring imbalance between the analysis of English Canada, based on exhaustive research using recognized sources, and the absence of reliable data in terms of French Canada. Readers see deftly documented statements concerning King's government and the Anglo-Canadian public service, but rarely anything more than often baseless generalizations about French Canada. This tendency to neglect gathering sufficient information on the history of Francophones and to offer hasty conclusions appears especially in the treatment of the Quebec press. In None is Too Many, fifteen statements appear regarding the opinions found in French-language newspapers, eight of which are made with no historical reference and eight are based on comments written by Anglophones at the time the crisis unfolded. ${ }^{34}$ According to Abella and Troper, French-language newspapers were unanimous on the topic of the refugees, rejecting any openness from the government on the topic and harbouring systematic hostility toward the Jews.

To reach these findings, the authors relied on comments prepared in the late thirties by employees of the American consulate in Montreal, by officials in the Canadian High Commission in London, and by activists at CJC at the same period. They even take the trouble to quote Roland Aubuchon, a police officer involved in monitoring alcohol smuggling in Abitibi Témiscamingue at the time of the events, who informed the CJC on the activities of Adrien Arcand. It is impossible to know whether these people read French fluently, or consulted all the French-language press or were simply expressing the prejudices of the people 
around them. At the very least, it would have been important to look critically at these sources and provide a more cautious reading of some of the findings given the flimsiness of the material used. No more recent studies or compilations are used to back up the authors' conclusions. Undoubtedly Abella and Troper would have been better off relying on the content of the message that Saul Hayes probably the best-informed Canadian at the time sent to the leaders of CJC in November 1943. The message, quoted in its entirety in None is Too Many, already contains the beginnings of a more moderated and balanced approach to deal with an issue that still deeply concerns research in Canadian Jewish studies.

By all reports based on examination of the press of Canada and even according to special reports prepared for government departments, anti-Semitism in Canada is rising among all sections and classes of the population. This is no less true among English-language groups than it is among the people of French Canada..$^{35}$

Overall, the new 2012 edition of None is Too Many raises fundamental questions that can no longer be evaded. To move forward and produce new knowledge, historians of Canadian Judaism must cease looking at French Canada as a marginal phenomenon not requiring serious, systematic, and comprehensive examination, in every way equal to how English Canada is examined. The complacency and superficiality of some authors' approaches usually distorts historical reality, often far removed from a subtle and balanced reading of the historic interactions we seek to better understand. Canadian Jewish history, by using flawed methodology and making do with brief overviews in its analysis of Francophone society, repeatedly comes up against a dead end. The same is true when it ignores works published by Francophone authors on the same topic or written by Canadianists from other disciplines. These attitudes are all the more surprising as for some years, new French-language research has been especially rich, and radically new interpretations have been put forward based on previously unpublished data. Instead of seeking to blame a still young field of research for its erring ways, we must hope that a new era of interdisciplinary and multilingual research will arise in the field of Canadian Jewish studies. The history of Judaism in our country has become a meeting point toward where several movements converge, one of which seeks to understand the evolution of French Canada in the face of the twentieth century's religious and cultural diversity. It presents us with an unexpected opportunity to broaden and delve more deeply into a field of study highly relevant for all specialists of Canadian history, and one which continues to attract talented young researchers. 


\section{1}

I refer primarily to the version of None Is Too Many republished in 2012. It is important to note here that the 2012 Edition is almost identical to that of 1982. Therefore, it is unnecessary to distinguish between reprints of the work.

\section{2}

On this topic, see Pierre Anctil, "Les rapports entre francophones et Juifs dans le contexte montréalais," in Les communautés juives de Montréal, histoire et enjeux contemporains, eds. Pierre Anctil and Ira Robinson (Quebec City: Septentrion, 2010), 38-64. See also Pierre Anctil, "Les Juifs montréalais à la rencontre de l'histoire canadienne," in Introduction aux études canadiennes. Histoires, identités, cultures, eds. Geoffrey Ewen and Colin M. Coates (Ottawa: University of Ottawa Press, 2012), 48-62.

\section{3}

See Harold Troper's remarks on this topic in The Defining Decade, Identity, Politics, and the Canadian Jewish Community of the 1960s (Toronto: University of Toronto Press, 2010), 32.

\section{4}

Review of Irving Abella and Harold Troper's book, None Is Too Many, in Recherches sociographiques [Quebec City], vol. 25, no. 1, January-April 1984, 138-41.

\section{5}

On this topic, see Luc Chartrand, "Le chanoine au pilori," L'Actualité, June 15, 1991, 114-5; "Le mythe du Québec fasciste," L'actualité, March 1, 1997, 20-30. See also Gary Caldwell, "La controverse Delisle-Richler," L'Agora, June 1994, 17-26.

\section{6}

One example: Stuart E. Rosenberg, The Jewish Community in Canada (Toronto: McClelland and Stewart, 1970), 2 vol.

\section{7}

For example, the work edited by Pierre Anctil and Ira Robinson, Les communautés juives de Montréal; histoire et enjeux contemporains (Quebec City: Septentrion, 2010), 275 p.; Les Juifs de Québec, quatre cents ans d'histoire, eds. Pierre Anctil and
Simon Jacobs (Presses de l'Université du Québec, 2015), 244 p. See Jean-François Nadeau, Adrien Arcand, führer canadien (Montréal: Lux Éditeur, 2010), 404 p.; Ignace Olazabal, Khaverim, Les Juifs ashkénazes de Montréal au début du XXe siècle, entre le shtetl et l'identité citoyenne (Montréal: Nota Bene, 2006), 275 p.; Chantal Ringuet, À la découverte du Montréal yiddish (Montréal: Fides, 2011), 300 p.; Hugues Théoret, Les chemises bleues : Adrien Arcand, journaliste antisémite canadien-français (Quebec City: Septentrion, 2012), 410 p.; Esther Trépanier, Peintres juifs de Montréal, témoins de leur époque, 1930-1948 (Montréal: Éditions de l'Homme, 2008), 287 p.; Denis Vaugeois, Les premiers Juifs d'Amérique, 1760-1860. L'extraordinaire histoire de la famille Hart (Quebec City: Septentrion, 2011), 382 p. The reader may also consult my two recent works, respectively titled Jacob-Isaac Segal (1896-1954), un poète yiddish de Montréal et son milieu (Quebec City: Presses de l'Université Laval, 2012), 447 p. and A chacun ses Juifs, 60 éditoriaux pour comprendre la position du Devoir à l'égard des Juifs, 1910-1947 (Quebec City: Septentrion, 2014), $452 \mathrm{p}$.

\section{8}

Irving Abella and Harold Troper, None Is Too Many: Canada and the Jews of Europe, 19331948 (Toronto: University of Toronto Press, 2012 [1983]), 17-8.

\section{9}

Abella and Troper, 164.

10

Abella and Troper, 10. Emphasis mine.

\section{1}

See Israël Medresh, Le Montréal juif entre les deux guerres [Tsvishn tsvey velt milkhomes] (Quebec City: Septentrion, 2001), 133-6. Translated from the Yiddish by Pierre Anctil. See the editorial by Henri Bourassa entitled "Leçons et réflexions," in Le Devoir, August 26, 1931: p. 1. The text is reproduced in its entirety in Pierre Anctil, À chacun ses Juifs : 60 éditoriaux pour comprendre la position du Devoir à l'égard des Juifs, 1910-1947 (Quebec City: Septentrion, 2014), 256-9. 


\section{2}

See Henri Bourassa's editorial: "Le péril de l'immigration, " Le Devoir, July 28, 1913. The text is reproduced in its entirety in Pierre Anctil, À chacun ses Juifs, 60 éditoriaux pour comprendre la position du Devoir à l'égard des Juifs, 1910-1947 (Quebec City: Septentrion, 2014), 112-6.

\section{3}

See Sandra Dubé, “Personne n'est antisémite, mais tout le monde est opposé à l'immigration : Discours des responsables politiques canadiens et québécois sur l'immigration, 1938-1945," Research report for a Masters degree in history (Université du Québec à Montréal: 2015), 167 p.

\section{4}

Abella and Troper, 50.

\section{5}

Abella and Troper, 278.

\section{6}

Abella and Troper, 65. Our italics.

\section{7}

Abella and Troper, 17.

\section{8}

Abella and Troper, 24.

\section{9}

See the arguments on this topic raised by Louis Rosenberg, Canada's Jews, A Social and Economic Study of Jews in Canada (Canadian Jewish Congress, 1939), 118-129. Other works to consult include Ninette Kelly and Michael Trebilcock, The Making of a Mosaic: a History of Canadian Immigration Policy (Toronto: University of Toronto Press, 2010), 689 p.; Valerie Knowles, Strangers at Our Gates: Canadian Immigration and Immigration Policy, 1540-2007 (Toronto: Dundurn, 2007), 310 p.

\section{0}

Abella and Troper, 61 .

\section{1}

Abella and Troper, 112.

\section{2}

See Pierre Anctil, Le rendez-vous manqué, les Juifs de Montréal face au Québec de l'entre deux-guerres (Quebec City: Institut québécois de recherche sur la culture, 1988), $357 \mathrm{p}$.

\section{3}

Abella and Troper, 45.

\section{4}

On this topic, see Michael Behiels, "The CECM and the Néo-Canadian Question, 1947-1963," Études ethniques au Canada / Canadian Ethnic Studies, vol. 8, no 2 (1986): 38-64.

\section{5}

Roger Duhamel, "Le problème de l'immigration et l'animosité antiquébécoise," Le Devoir, December 16, 1943: p. 1. See also Gérard Yelle, "L'immigration anglaise au Canada," Le Devoir, January 22, 1945: p. 1.

\section{6}

For a biography of Silcox, see Alan Davies, "Clarence Edwin Silcox (1888-1961): Brave and Resolute Champion of the City of God," Touchstone, vol. 27, no 2, May 2009: p. 50-57. The following work may also be consulted: Alan Davies and Marilyn Nefsky, How Silent Were the Churches? Canadian Protestantism and the Jewish Plight during the Nazi Era (Waterloo, Wilfrid Laurier University Press, 1997), 195 p. Unfortunately, in their work, the co-authors chose not to look at the position of the Francophone Catholic Church.

\section{7}

Pierre Anctil, "Uneven Perceptions; Kristallnacht in the Yiddish and Francophone Press of Montreal," in Violence, Memory and History; Western Perceptions of Kristallnacht, eds. Colin McCullough and Nathan Wilson (New York, Routledge, 2015), 90-107.

\section{8}

See the complete list of these editorials and the dates they appeared in Pierre Anctil, À chacun ses Juifs: 60 éditoriaux pour comprendre la position du Devoir à l'égard des Juifs, 19101947 (Quebec City: Septentrion, 2014), 423-35.

\section{9}

Pierre Anctil, À chacun ses Juifs: 60 éditoriaux pour comprendre la position 
Special Insert to Canadian Jewish Studies, Vol 26 (2018) /

Livret spécial attaché à Études juives canadiennes, Vol 26 (2018)

du Devoir à l'égard des Juifs, 1910-1947

(Quebec City: Septentrion, 2014), 56.

\section{0}

Georges Pelletier, "La vague de l'immigration," Le Devoir, October 1912: p. 1.

\section{1}

Letter of Reverend Clarence E. Silcox quoted

by Roger Duhamel, op. cit.

\section{2}

From 1924 until his death in 1941, Lapointe was a minister in Mackenzie-King's cabinet. He was considered one of the most influential Francophone politicians in the country. On this topic, see John Macfarlane, Ernest Lapointe and Quebec's Influence on Canada's Foreign Policy (Toronto: University of Toronto Press, 1999), 288.

\section{3}

This is a series published by the Archives of the Canadian Jewish Congress in Montreal: Kenneth Kerneghan, Freedom of Religion in the Province of Quebec: With Particular Relevance to Jews, Jehovah's Witnesses and Church-state Relations 1930-1960, Ph.D. thesis in Political Science (Durham, N. C.: Duke University 1966), 347 p.; Lita-Rose Betcherman, The Swastika and the Maple Leaf: Fascist Movements in Canada and in the Thirties (Toronto: Fitzhenry and Whiteside, 1975), $167 \mathrm{p}$.

\section{4}

In the case of Le Devoir, Abella and Troper's reading of three texts is wrong and biased; one appeared on April 22, 1943, written by Léopold Richer, and two others by Alexis Gagnon appeared on March 25 and September 13, 1946.

\section{5}

Abella and Troper, 161 . 
